\author{
Konrad Klejsa \\ Uniwersytet Łódzki
}

\title{
Drezno i Gustloff - miejsca pamięci niemieckich ofiar II wojny światowej i ich reprezentacje $w$ filmach telewizyjnych stacji ARD i ZDF z lat 2006-2008
}

Współczesna politykę historyczną Republiki Federalnej Niemiec określa się w języku niemieckim terminem „normalizacja” (Normalisierung) ${ }^{1}$. Polityka ta - faktycznie zainicjowana przez rząd Helmuta Kohla w II poł. lat osiemdziesiątych - pozostawała w kontrze do pedagogiczno-prokuratorskiej polityki pamięci pokolenia 1968 roku, które - zdaniem Petera Schneidera - „wymazało ze swej wizji historii wszystkie obrazy Niemców niewpisujące się w ramy pojęcia "pokolenie sprawców»"2. Owa „normalizacja” polegać miała, najogólniej rzecz ujmujac, na zaakceptowaniu dwóch twierdzeń. Po pierwsze, nazizm winien być traktowany jako jedna z historycznych epok - nie zaś postrzegany jako kulminacja niemieckiego Ordnung czy kumulacja specyficznych cech niemieckiej kultury. Po drugie zaś - doświadczenia „zwykłych Niemców” nie moga być przywoływane jedynie w charakterze „dowodu sądowego”, lecz w sposób podobny do będacego udziałem innych narodów; innymi słowy, „normalizacja” polegać by miała na odzyskaniu prawa do publicznego wyrażania żalu z powodu cierpień poniesionych przez własny naród (nie tylko za sprawa nazistów, lecz także bombardowań aliantów i wypędzeń z terytoriów wschodnich). Właśnie ten aspekt był w połowie lat dziewięćdziesiątych krytykowany przez polityków i publicystów orientacji lewicowo-liberalnej, przestrzegających przed „znormalizowanym nacjonalizmem”, którego rzekomym dowodem miał być podpisany przez ponad 300 luminarzy niemieckiej kultury i nauki list opublikowany

${ }^{1} \mathrm{Na}$ temat przekształceń niemieckiej pamięci zbiorowej w kontekście dyskursów politycznych zob.: Anna Wolff-Powęska, Pamięć - brzemie historii, Poznań 2011, s. 330-395; Wojciech Pięciak, Niemiecka pamięć. Wspótczesne spory $w$ Niemczech o miejsce III Rzeszy $w$ historii, polityce i tożsamości, Kraków 2002; Kazimierz Wóycicki, Niemiecki rachunek sumienia. Niemcy wobec przeszłości 1933-1945, Wrocław 2004.

${ }^{2}$ Peter Schneider, Deutsche als Opfer. Über ein Tabu der Nachkriegsgeneration, [w:] Ein Volk von Opfern? Die neue Debatte um den Bombenkrieg, red. Lothar Kettenacker, Berlin 2003.

${ }^{3}$ Peter Glotz, Die falsche Normalisierung, Frankfurt am Main 1994. 
w „Frankfurter Allgemeine Zeitung” w kwietniu 1995 roku na okoliczność przypadającej kilka dni później 50 rocznicy zakończenia wojny ${ }^{4}$ (jego autorzy przypominali, że 8 maja w pamięci Niemiec nie oznacza wyłącznie końca nazizmu, a także początek wysiedleń i podziału kraju). Z czasem jednak hasło „normalizacji” przejęte zostało przez polityków opcji lewicowo-liberalnej, co znalazło wyraz w wielu decyzjach podejmowanych przez koalicję SPD-Zieloni i kanclerza Schrödera ${ }^{5}$.

„Normalizacja” oznaczała zatem takie sprofilowanie pamięci historycznej, które nie byłoby wyłącznie obciążeniem dla budowania nowej (pozjednoczeniowej) tożsamości niemieckiej. Zmiana ta wynikała w oczywisty sposób także z przemian demograficznych. Interesujące wyniki przyniosła przeprowadzona w 1995 roku ankieta tygodnika „Der Spiegel”. 16 procent spośród ankietowanych powyżej 65 roku życia było zdania, że 1 września 1939 roku to Polska rozpoczęła wojnę (tego zdania było 3 procent osób w wieku 18-34 lata). W pierwszej grupie respondentów 63 procent gotowych było bronić opinii, że Wehrmacht nie był współwinny zbrodni wojennych (przeciwnego zdania było 71 procent z grupy drugiej). Z poglądem, iż wypędzenie etnicznych Niemców z terytoriów wschodnich było zbrodnią porównywalną z Holokaustem, zgodziło się 44 procent osób z wykształceniem zawodowym i 20 procent osób po maturze ${ }^{6}$.

Zarazem jednak pamięć młodszego pokolenia naznaczona była nieuchronnie tymi sposobami rozumienia historii, które charakterystyczne były dla starszych pokoleń: generacji dziadków raczej niż ojców. Wydarzeniem naukowym (ale też medialnym) stała się w Niemczech publikacja książki Haralda Welzera i jego zespołu pod wymownym tytułem Dziadek nie byt nazista ${ }^{7}$. Praca stanowiła pokłosie projektu badawczego, w toku którego poddano analizie rozmowy o latach nazizmu i II wojny prowadzone w czterdziestu niemieckich rodzinach ${ }^{8}$. Wyniki badań uświadomiły, że w niemieckich rodzinach o historii mówi się w dwojaki sposób - z jednej strony, językiem oficjalnego Leksykonu (będącego kolekcją faktów historycznych), z drugiej zaś - rodzinnego Albumu (emocjonalnie naznaczonego zbioru wspomnien - autentycznych, lub zapośredniczonych przez widowiska medialne). Na podstawie przeprowadzonych wywiadów można było sądzić, konkludował Welzer, że „antysemitów i sprawców w niemieckich rodzinach nie było [...] bez względu na to, kogo można winić za Holocaust, kto jest odpowiedzialny za wyniszczająca wojne, prace przymusowa i obozy koncentracyjne - jedna rzecz wydaje się pewna dla niemal wszystkich obywateli Republiki Federalnej: dziadek nie był nazista”.

${ }^{4}$ 8. Mai 1945 - Gegen das Vergessen, "Frankfurter Allgemeine Zeitung”, 28 kwietnia 1995.

${ }^{5}$ Zob. Zbigniew Mazur, Nowy patriotyzm niemiecki, „Przegląd Zachodni” 2008, nr 1.

${ }^{6}$ Die Jungen denken anders, "Der Spiegel” 1995, Nr. 19.

${ }^{7}$ Polski przekład fragmentu książki: Harald Welzer et al.: „Dziadek nie byt nazista”. Narodowy socjalizm i Holocaust w pamięci rodzinnej, [w:] Pamięć zbiorowa i kulturowa. Wspótczesna perspektywa niemiecka, red. Magdalena Saryusz-Wolska, Kraków 2009.

${ }^{8}$ Podobna, wcześniej wydana praca (Der Holocaust in Leben von drei Generationen, red. Gabriele Rosenthal, Giessen 1997) nie zyskała takiego rezonansu medialnego.

${ }^{9}$ H. Welzer et al., op. cit., s. 247-248. 
Historyk Norbert Frei, w swej książce krytykującej „normalizację” polityki pamięci w zjednoczonych Niemczech ukuł zgrabną formułę ujmująca jeden z aspektów owej polityki. Zdaniem Freia, mamy do czynienia ze znaczącym przesunięciem głównego przedmiotu jej zainteresowań: „od ofiar Niemców do Niemców jako ofiar"10. Symbolami tej zmiany stały się cierpienia ludności cywilnej w miastach bombardowanych przez aliantów zachodnich, z drugiej zaś - die Vetriebene („wypędzeni”) wysiedleni ze wschodnich landów III Rzeszy. Dyskurs na temat Wypędzonych uległ zresztą istotnej przemianie: o ile wcześniej był wyłączony z oficjalnej, politycznie poprawnej narracji polityki historycznej, o tyle pod koniec lat dziewięćdziesiątych publikacje o Wypędzonych z większą niż onegdaj częstotliwością zaczęły się pojawiać w mediach głównego nurtu ${ }^{11}$. Wysiedlenia zostały włączone do monumentalnej pracy o niemieckich miejscach pamięci (będącej de facto leksykonem głównych pojęć niemieckiej kultury $)^{12}$, były także przedmiotem licznych badań naukowych - historyków (opracowana $\mathrm{w}$ latach osiemdziesiatych dokumentacja wysiedlonych została wydana ponownie w 2004 roku) oraz literaturoznawców (klasyczna monografia na ten temat doczekała się w latach dziewięćdziesiątych aż trzech wznowien ${ }^{13}$ ); o wypędzonych traktowały zreszta liczne wydane już po zjednoczeniu powieści ${ }^{14}$. W 2002 roku w tygodniku „Der Spiegel” ukazała się seria artykułów na temat wypędzeń ( $\mathrm{w}$ materiale wprowadzajacym do cyklu czytamy wprost: „Minęły już czasy dominacji tych [Wortführer], którzy koncentrowali się wyłącznie na zbrodniach popełnionych przez nazistów i ich sprzymierzeńców"15); rok wcześniej zaś stacje niemieckiej telewizji publicznej zaprezentowały serie dokumentów o wypędzonych: ARD nadało trzyczęściowy cykl Wypędzeni. Ostatnie ofiary Hitlera (Die Vertriebenen. Hitlers letzte Opfern, real. Henry Köhler, Sebastian Dehnhardt, Christian Frey $\left.{ }^{16}\right)$, zaś ZDF - pięcioczęściowy

${ }^{10}$ Norbert Frei, 1945 und wir. Das Dritte Reich im Bewusstsein der Deutschen, München 2005, s. 14. Na zjawisko to zwracali uwagę liczni komentatorzy - szczególnie często w piśmiennictwie anglojęzycznym. Zob. Helmut Schmitz, The Return of Wartime Suffering in Contemporary German Memory Culture, Literature and Film, [w:] A Nation of Victims? Representations of German Wartime Suffering from 1945 to the Present, red. Helmut Schmitz, Amsterdam 2007; Stuart Taberner, Normalisation, the New Consensus on the Nazi Past and the Problem of German Wartime Suffering, "Oxford German Studies" 2002, No. 31.

${ }^{11}$ Zob. także: Hans Henning Hahn, Jak w Niemczech pamięta się o wypędzeniu, "Borussia" 2007, nr 4 .

${ }^{12}$ Deutsche Erinnerungorte, red. Hagen Schultze, Etienne François, München 2001.

${ }^{13}$ Louis Ferdinand Helbig, Der ungeheure Verlust. Flucht und Vertreibung in der deutschsprachigen Belletristik, Wiesbaden 1996.

${ }^{14}$ Przykładowo: Reinhard Jirgl, Niedopetnieni, przeł. R. Wojnakowski, Olsztyn 2009 (org. 2003).

${ }^{15}$ Hans-Joachim Noack, Die Deutsche als Opfer, "Der Spiegel” 2002, Nr. 13, s. 37. W kolejnych numerach opublikowano artykuły Thomasa Darnstädta i Klausa Wiegrefego pod tytułami Biegiem, świnie oraz Diabelskie rozwiazanie (Lauft, ihr Schweine!, "Der Spiegel 2002", Nr. 14; Eine teuflische Lösung, "Der Spiegel” 2002, Nr. 15). W tym samym roku wydawca „Spiegla” wprowadził na rynek odrębny zeszyt monograficzny o tej tematyce ("Spiegel Spezial" 2002, Nr. 2 - w całości dostępny przez http://www.spiegel.de/spiegel/spiegelspecial/index-2002-2.html).

${ }^{16}$ Serii towarzyszyła publikacja książkowa: Hans Lemberg, Erik Frenzen, Die Vertriebene, Hitlers letzte Opfern, Berlin 2002. 
cykl Guido Knoppa Wielka ucieczka (Die grosse Flucht), który według danych telemetrycznych osiagnął widownię na poziomie 5 milionów ${ }^{17}$. Realizacje te bywały przedmiotem krytyki także w Niemczech - w 2008 roku Tanja Dückers ostrzegała przed „medialnym rewizjonizmem historycznym nowego rodzaju”, pisząc: „Największe stacje telewizyjne dostarczaja Knoppagandy, która sugeruje, że niemiecki naród - pomijając dobrze już nam znanych najwyższych funkcjonariuszy partii nazistowskiej - składał się wyłącznie z oszukanych, zbombardowanych, zgwałconych i sadystycznie pomordowanych"18. Opinia ta potwierdza, że filmy Knoppa można i należy czytać przez pryzmat działalności Związku Wypędzonych ${ }^{19}$. I choć faktyczna rola polityczna Eriki Steinbach (byłej już szefowej Związku Wypędzonych) jest w Niemczech nieporównywalnie mniejsza, niż mogłoby się zdawać z licznych materiałów jej poświęconych w polskich mediach, to niewatpliwie za sprawa jej aktywności historie Wypedzonych trafiły na agendę oficjalnej polityki historycznej $\mathrm{RFN}^{20}$.

\section{Reprezentacje nazizmu we współczesnym kinie niemieckim - wprowadzenie}

Jak słusznie zauważyła Ewa Fiuk, „Liczba filmów zrealizowanych od roku 1990 pokazujących niemieckie cierpienie i ofiarność podczas lat wojny przewyższa liczbę utworów o podobnej tematyce powstałych w ciagu czterech dziesięcioleci (1950-1990)"21. O randze tematu historycznego we współczesnym kinie niemieckim nie świadczy tylko ilość filmów, ale także fakt, iż wiele z nich miało znakomitą dystrybucję i wyniki frekwencyjne ${ }^{22}$. Niektóre odniosły także sukces międzynarodowy - kilka niemieckich filmów fabularnych nakręconych po 1989 roku zostało nominowanych do Oscara: Schtonk! (reż. Helmut Dietl, 1992), Upadek (Der Untergang, reż. Oliver Hirchbiegel, 2004), Sophie Scholl - ostatnie dni (Sophie Scholl - die letzte Tage, reż. Marc Rothemund, 2006)

${ }^{17}$ Za: Helmut Schmitz: The Birth of the Collective from the Spirit of Empathy: From the 'Historians' Dispute' to German Suffering, [w:] Germans as Victims, ed. Bill Niven, Basingstoke 2006, s. 94.

${ }^{18}$ Tanja Dückers, Alles nur Opfer, "Zeit”, 5 marca 2008. Przy okazji zauważyła autorka, że z użycia wychodzi termin „generacja sprawców” (Tätergeneration), który został zastapiony przez określenie „pokolenie świadków” (Zeitzeugengeneration).

${ }^{19}$ Pod kierownictwem Koppa powstał także trzyodcinkowy miniserial Dzieci Ucieczki (Die Kinder der Flucht, reż. Hans-Christoph Blumenberg, 2006).

${ }^{20}$ Związek Wypędzonych w 2006 roku zorganizował wystawę Wymuszone drogi. Ucieczka $i$ wypędzenie w Europie XX wieku (Erzwungene Wege - Flucht und Vertreibung im Europa des 20. Jahrhunderts), zaś dwa lata później rząd Angeli Merkel podjał decyzję o utworzeniu fundacji Ucieczka, Wypędzenie, Pojednanie (Flucht, Vertreibung, Versöhnung), której głównym celem jest budowa centrum upamiętniajacego wypędzenia (Sichtbares Zeichen).

${ }^{21}$ Ewa Fiuk, Inicjacje, tożsamość, pamięć. Kino niemieckie na przełomie wieków, Wrocław 2012, s. 58.

${ }^{22}$ Obszerny katalog filmów i tematów dotyczących reprezentacji nazizmu we współczesnym kinie niemieckim przynosi praca: Joanna Trajman, Narodowy socjalizm w kinie zjednoczonych Niemiec, Wrocław 2014. 
czy Nigdzie w Afryce (Nirgendwo in Afrika, reż. Caroline Link, Oscar w 2003). Audiowizualne historie nazizmu to oczywiście nie tylko kino, lecz - kto wie, czy nie należałoby powiedzieć: przede wszystkim - programy telewizyjne. W Niemczech wyspecjalizował się w nich Guido Knopp, który w telewizji ZDF (II program niemieckiej telewizji publicznej) kieruje zespołem specjalizujacym się $\mathrm{w}$ realizacjach z gatunku histotainment ${ }^{23}$.

Mnogość filmów o latach nazizmu i II wojny skłoniła Lutza Koepnicka do sformułowania hipotezy o „nazi heritage cinema” ${ }^{24}$. Sam termin wydaje mi się cokolwiek ryzykowny (heritage - dziedzictwo, spuścizna - jest zazwyczaj wartościowane pozytywnie), zasadna natomiast jest argumentacja, zgodnie z która filmy interesujące Koepenicka „przedstawiają epokę historyczna z perspektywy post-pamięci” i sa adresowane przede wszystkim do widza, którego wiedza o niej nie opiera się ani na bezpośrednim doświadczeniu, ani na międzypokoleniowych rozmowach, ale w pierwszej kolejności na innych reprezentacjach medialnych. Z kolei Sabine Hake zauważyła, że konsekwencja przyjęcia takiej post-historycznej perspektywy jest konwencjonalizacja widowiska:

Jak gdyby potwierdzając diagnozę o stopniowym zastępowaniu historii przez symulację i spektakl, stawianą przez teoretyków postmodernizmu, nowe próby radzenia sobie z przeszłością wydaja się bardziej konwencjonalne w swym zaufaniu efektowi identyfikacji wywoływanej przez klasyczna narrację i bardziej konserwatywne w znaczeniu tego, co osobiste dla tego, co polityczne ${ }^{25}$.

Jako paradygmatycznego twórce „posthistorycznego” wymienia się najczęściej Josefa Vilsmaiera (np. Stalingrad, Niemcy 1993), którego filmy - zdaniem Hake - mają charakter „rewizjonistyczny” i „przyczyniają się do normalizacji niemieckiej historii, ograniczajac ją do wizualnego spektaklu”26. Zgadzam się z tą opinia, choć jej argumentacja u Hake oparta jest na ryzykownym „równaniu" (sukces komercyjny = trywializacja problemu = rewizjonizm historyczny), które wynika najpewniej z przyjęcia założenia faworyzującego modernistyczną wizję kina autorskiego.

O wiele istotniejsze od zagadnień związanych ze stylem wizualnym zdaja mi się kwestie związane z dramaturgią, która u Vilsmeiera często rozkłada akcenty w taki oto sposób, by uwypuklić różnice między „dobrymi Niemcami

${ }^{23}$ Hannes Heer, "Hitler war's”. Die Berfreiung der Deutschen von ihrer Vergangenheit, Berlin 2005 (rozdział Guido Knopp: Hitlers Helfer. Die Rückkehr der Geschichte als Nazi-Clip); Frank Bösch, Holokaust mit ,K'. Audiovisuelle Narrative in neueren Fernsehdokumentationen, [w:] Visual History. Die Historiker und die Bilder, red. Gerhard Paul, Göttingen 2006; Wulf Kansteiner, Die Radikaliesierung des Hitler und das Dritte Reich in den Fernsehdokumentationen von Guido Knopp, "Zeitschrift für Geschichtswissenschaft" 2003, Nr. 51; przedruk w: idem, In Pursuit of German Memory. History. Television and Politics after Auschwitz, Athens-Ohio 2006; Oliver Näpel, Historisches Lernen durch 'Dokutainment'? Chancen und Grenzen einer neuen Ästhetik populärer Geschichtsdokumentationen, analysiert am Beispiel der Sendereihen Guido Knopps, "Zeitschrift für Geschichtsdidaktik” 2003, Nr. 2.

${ }^{24}$ Lutz Koepenick, Reframing the Past: Heritage Cinema and the Holocaust in the 1990s, "New German Critique" 2002, No. 87.

${ }^{25}$ Sabine Hake, German National Cinema, London 2002, s. 186-187.

${ }^{26}$ Ibidem., s. 187. 
i złymi nazistami”. Ten wzór narracyjny stosowany był powszechnie w zachodnioniemieckich filmach wojennych lat pięćdziesiątych, do którego repozytorium często sięga także współczesna kinematografia $\mathrm{RFN}^{27}$. W 2001 roku premiere miała także nowa wersja serialu Jeniec: jak daleko nogi poniosa (So weit die Füsse tragen, reż. Hardy Martin) - remake cyklu pod tym samym tytułem z 1959 roku, opartym na rzekomych przeżyciach niemieckiego jeńca, który kilka lat po wojnie powrócił z zesłania na Dalekim Wschodzie ${ }^{28}$. Jak słusznie zauważa Ewa Fiuk, serial zrealizowano w konwencji Kina Nowej Przygody (egzotyczna sceneria, pełna nieoczekiwanych zwrotów akcji, pościgi i strzelaniny rodem z westernu, oraz „wątek miłosny, będący niewybrednym echem idei porozumienia kultur"29). Z kolei w 2008 roku stacja PRO 7 nadała nowa wersję filmu Most (Die Brücke, reż. Wolfgang Panzer) - rimejk klasycznego filmu Bernharda Wickiego pod tym samym tytułem (1959) - zbierając 3,5 milionów widzów, w tym niemal 20 procent udziału w grupie młodzieży ${ }^{30}$. Największą widownię miały jednak filmy telewizyjne: Drezno (Dresden, reż. Roland Suso Richter, Niemcy 2006), Ucieczka (Die Flucht, reż. Kai Wessel, 2007) oraz Gustloff - rejs ku śmierci (Die Gustloff, reż. Joseph Vilsmaier, Niemcy 2008). Pierwsza i trzecia odsłona tego cyklu traktowały o dwóch symbolach niemieckich cierpień - zbombardowanym Dreźnie oraz zatopionym okręcie Wilhelm Gustloff.

\section{Bombardowanie Drezna jako temat fabularny}

W 1999 roku krytyk literacki Winfried Sebald opublikował w formie książkowej swoje wykłady (wygłoszone dwa lata wcześniej w Zurychu) Wojna powietrzna i literatura ${ }^{31}$, w których zwrócił uwage na słaba obecność tematu bombardowań niemieckich miast w rodzimej literaturze. Krytycy pracy Sebalda twierdzili jednak, że jego kwerenda nie była dokładna ${ }^{32}$ : o bombardowaniach pisali bowiem m.in. Heinrich Böll, Herman Kasack, Hans Nossack, Eric Maria

${ }^{27}$ I nie tylko lat pięćdziesiątych - w 1995 roku ukazał się literacki sequel wydanej w 1973 roku (i zekranizowanej przez Wolfganga Petersena w 1982 roku) powieści Okręt, opowiadającej o losach żołnierzy niemieckiej łodzi podwodnej w latach 1943-1944.

${ }^{28}$ Josef Martin Bauer, So weit die Füße tragen, München 1955 (51 wydań w ciagu 51 lat!). W 2010 roku śledztwo dziennikarskie ujawniło, że w opowieści jest wiele przekłamań; http://www. sueddeutsche.de/kultur/falsche-nachkriegserinnerungen-der-schnee-von-gestern-1.12263 [dostęp: 13 września 2013].

${ }^{29}$ E. Fiuk, op. cit., s. 63.

${ }^{30}$ Dane za: Manuel Köppen, The Rhetoric of Victim. Narratives in West German Films of the 1950s, [w:] Screening War. Screening War. Perspectives on German Suffering, eds. Paul Cooke, Marc Silberman, New York 2010, s. 71. W porównaniu z klasyczną wersją, pojawiły się nowe wątki, które rozpatrywać można w kontekście „niemiecko-żydowskiego pojednania”: ojciec jednego z chłopców chce wysłać do Dachau nauczycielkę Waltera, z która syn ma romans, zaś nawołujacy bohaterów do poddania się amerykański żołnierz, w oryginale bezimienny, tu zyskał nazwisko Rosenzweig.

${ }^{31}$ Winfried G. Sebald, Wojna powietrzna i literatura, przeł. M. Łukasiewicz, Warszawa 2012.

${ }^{32}$ Andreas Huyssen, Rewriting and New Beginnings: W. G. Sebald and the Literature on the Air War, [w:] idem, Present Pasts: Urban Palimsests and the Politics of Memory, Stanford 2003. 
Remarque, Arno Schmidt i Dieter Forte. Potwierdziły to ksiażki przygotowane wkrótce potem przez Volkera Hage (kierownika działu literackiego „Spiegla”): zbiór wywiadów z pisarzami i krytykami literackimi (byli wśród nich Walter Kempowski, Monika Maron, Marcel Reich-Ranicki, Winfried Sebald, także Alexander Kluge) oraz antologia prac literackich o bombardowaniu Hamburga w 1943 roku $^{33}$. Hage podkreślał, że słaba obecność tematu bombardowań w literaturze niemieckiej nie wynika z ilościowych parametrów produkcji artystycznej, ale była efektem słabej ich recepcji ${ }^{34}$. W RFN naloty bombowe na niemieckie miasta istniały w pamięci zbiorowej i kulturowej ${ }^{35}$, ale nie były włączane do oficjalnej polityki pamięci (USA i Wielka Brytania były wszak sojusznikami RFN w NATO). Inaczej w NRD ${ }^{36}$, gdzie w szczególności Drezno stało się synonimem alianckiego okrucieństwa, co w gruncie rzeczy powielało Goebbelsowska propagandę w końca wojny ${ }^{37}$.

Po zjednoczeniu temat ten stał się jednym $\mathrm{z}$ węzłowych punktów nowej pamięci historycznej: w 1995 roku oficjalnym wydarzeniom rocznicowym nadano szczególnie staranną i podniosłą oprawę ${ }^{38}$. W latach dziewięćdziesiątych Wydawnictwo Wartberg wydało serię albumów historycznych o bombardowaniach konkretnych miast (Bonn, Mannheim, Ludwigshafen, Hanower, Lipsk, Kassel, Magdeburg, Drezno); w materiale ilustracyjnym i opisie eksponowano cywilne ofiary nalotów, co mogło wywoływać wrażenie masakry niewinnych społeczności. Wydarzeniem wydawniczym stał się multimedialny collage Waltera Kempowskiego Echolot. Zbiorowy pamiętnik. Zima 1945 roku $^{39}$ (składajacy się z wyimków gazetowych, raportów wojskowych, fragmentów pamiętników itp.), publikowany w latach 1993-2005 w czterech tomach, które zostały

${ }^{33}$ Volker Hage, Zeugen der Zerstörung: Die Literaten und der Luftkrieg, Frankfurt am Main 2003; idem, Hamburg 1943: Literarische Zeugnisse zum Feuersturm, Frankfurt am Main 2003.

${ }^{34} \mathrm{~V}$. Hage, Zeugen der Zerstörung, s. 119.

${ }^{35}$ Najbardziej znana jest poetycka relacja Gerharta Hauptmanna (Gerhart Hauptmann, Dresden, [w:] idem, Sämtliche Werke, red. Hans-Egon Hass, tom XI, Frankfurt am Main 1974).

${ }^{36}$ Zarazem jednak w NRD nie zrealizowano pełnometrażowego filmu kinowego o bombardowaniach Drezna. Ciekawy w tym kontekście jest przypadek filmu Jana Rybkowskiego $D z i s ́$ w nocy umrze miasto (1961), który - choć został nakręcony przy wsparciu Defy - nigdy nie wszedł do repertuaru kin NRD, z powodów, których objaśnienie wymagałoby zapewne kwerendy w niemieckich archiwach (film Rybkowskiego był jedna z nielicznych polskich produkcji zakupionych do dystrybucji w RFN).

${ }^{37}$ Gilad Margalit, Der Luftkrieg auf Dresden. Seine Bedeutung für die Erinnerungspolitik der DDR, [w:] Narrative der Shoah, red. Susanne Düwell, Matthias Schmidt, Paderborn 2002; idem, Dresden and Hamburg - Official Memory and Commemoration of the Victims of Allied Air Raids in the two Germanies, [w:] A Nation of Victims?; Thomas Widera, Gefangene Erinnerung: Die politische Instrumentalisierung der Bombardierung Dresdens, [w:] Alliierter Bombenkrieg: Das Beispiel Dresden, red. Lothar Fritze, Thomas Widera, Göttingen 2005; Matthias Neutzner, Vom Alltäglichen zum Exemplarischen. Dresden als Chiffre für Luftkrieg der Allierten, [w:] Das Rote Leuchten: Dresden und der Bombenkrieg, red. Oliver Reinhard, Matthias Neutzner, Dresden 2005; Malwina Orepuk, Skażona pamięć o bombardowaniach Drezna, „Kultura Współczesna” 2008, nr 4.

${ }^{38}$ Thomas W. Neumann, Der Bombenkrieg: Zur ungeschriebenen Geschichte einer kollektiven Verletzung, [w:] Nachkrieg in Deutschland, red. Klaus Naumann, Hamburg 2001, s. 35.

${ }^{39}$ Walter Kempowski, Das Echolot. Fuga furiosa. Ein kollektives Tagebuch. Winter 1945. München 1999-2005. 
uzupełnione przez osobny wolumin o bombardowaniach Drezna ${ }^{40}$. Również na polu badań historycznych dało się zauważyć wzrost zainteresowania tą tematyką: już w 1990 roku wydano ksiazżke Olafa Groehlera (historyka z NRD) ${ }^{41}$, na początku XXI wieku - monumentalna prace przygotowana przez zespół Horsta Booga $^{42}$, w 2003 roku „Der Spiegel” przygotował zaś specjalny dodatek tematyczny Gdy $z$ ognia lat sie ogień (Als Feuer vom Himmel fiel) ${ }^{43}$.

$\mathrm{Z}$ największym zainteresowaniem medialnym - i fala polemik - spotkała się jednak książka publicysty Jörga Friedricha Pożoga, która ukazała się w 2002 roku (sukces czytelniczy tomu - fragmenty ukazywały się w poczytnym „Bildzie” - sprawił, iż kilka miesięcy później autor wydał kolejny wolumin, tym razem majacy formę albumu zdjęc komentowanych przez wyimki literackie $)^{44}$. Krytycy książki ${ }^{45}$ wskazywali na liczne błędy faktograficzne (Horst Boog ubolewał: „Gdyby tylko Friedrich dodał podtytuł: «powieśc», można byłoby powiedzieć «To fantastyczne!»" $\left.{ }^{46}\right)$, kwestionowali na przykład zawyżone dane dotyczące liczby ofiar (według Friedricha, zginęło wówczas 600 tysięcy cywilów; wspomniany już Groehler szacuje tę liczbę między 350 a 370 tysięcy ${ }^{47}$ ) oraz wielokrotnie podkreślana przez Friedricha (błędną) opinię, iż celem nalotów nie było zniszczenie celów militarnych, lecz osłabienie morale ludności cywilnej. Poddawano w watpliwość przyjęte w Pożodze strategie retoryczne, prezentujące wyłącznie punkt widzenia ofiar oraz budujące ich osobliwa wspólnotę (poprzez podkreślanie, że bomby zabijały ukrywających się Żydów, robotników przymusowych i „zwykłych” Niemców). Przede wszystkim jednak krytykowano dekontekstualizację i uniwersalizację nalotów, usuwające z pola widzenia przyczynowo-skutkowy związek między nazizmem a bombardowaniami ${ }^{48}$. Owa uniwersalizacja dokonywana jest przez Friedricha za pomoca nieadekwatnych do przedmiotu opisu wyborów leksykalnych: z jednej strony, wykorzystujących sztance znane z nazistowskiej propagandy (pisał o „masakrze” i „eksterminacji”), z drugiej zaś - przyrównujacych naloty bombowe do zbrodni popełnianych przez nazistowski

\footnotetext{
${ }^{40}$ Walter Kempowski, Der rote Hahn. Dresden in Februar 1945, München 2001.

${ }^{41}$ Olaf Groehler, Bombenkrieg gegen Deutschland, Berlin 1990.

${ }^{42}$ Horst Boog et al., Das deutsche Reich in der Defensive. Strategischer Luftkrieg in Europa, Stuttgart 2001.

${ }^{43}$ Als Feuer vom Himmel fiel: Der Bombenkrieg in Deutschland, red. Stephan Burgdorff, Christian Habbe, München 2003, http://www.spiegel.de/spiegel/spiegelspecial/index-2003-1.html [dostęp: 20.04.2013].

${ }^{44}$ Jörg Friedrich, Pożoga: bombardowania Niemiec w latach 1940-1945, przeł. Paulina Dziel, Damian Kocur, Jan Liniwiecki, Warszawa 2011; idem, Die Brandstätten. Der Anblick des Bombenkriegs. München 2003.

${ }^{45}$ Świadectwem debaty wokół pracy Friedricha jest zbiór Ein Volk von Opfern? Die neue Debatte um den Bombenkrieg, 1940-1945, red. Lothar Kettenacker, Berlin 2005. Tom otwiera całkiem zasadnie - artykuł o ataku na Wieluń 1 wrzesnia 1939 roku (Joachim Trenkner, Wieluń 1. September 1939: Keine besondere Feindbeobachtung); spośród autorów reprezentowanych w tomie w zasadzie tylko Martin Walser komplementował Friedricha za kunszt narracji i obiektywny styl (Martin Walser, Bombenkrieg als Epos).

${ }^{46}$ Horst Boog, Kolossalgemälde des Schreckens, [w:] Ein Volk von Opfern..., s. 136.

${ }^{47}$ O. Groehler, op. cit., s. 320.

${ }^{48}$ Zob. wywiad z Danem Dinerem: Anthropologisierung des Leidens, "Phase" 2003, Nr. 9.
} 
totalitaryzm. I tak, brytyjskie i amerykańskie eskadry lotnicze określił Friedrich jako Einsatzgruppen (nazwę taka nosiły oddziały likwidacyjne SS), płonące biblioteki - jako Bücherverbrennung (terminem tym określa się palenie ksiazżek przez NSDAP), piwnice odcięte od dopływu powietrza - jako Gaskeller (krematoria), ofiary cywilne - jako Gefallene (czyli „poległych na froncie”), cała operacje - jako Vernichtungskrieg (wojnę totalna, ukierunkowaną na wyniszczenie narodu lub grupy etnicznej - tak kierownictwo NSDAP określało operacje Barbarossa i kampanię przeciw „żydowskiemu bolszewizmowi”). Wreszcie, sam tytuł książki (org. Brand) sugerował domniemany związek nalotów bombowych z Holokaustem („ofiarą całopalna”). Zabiegi te Aleida Assmann całkiem zasadnie określiła jako „semantyczny transfer pojęć wyjętych z dyskursu o Zagładzie”49.

Popularność tematyki nalotów bombowych i jej rangę we współczesnym niemieckim dyskursie pamięci można tłumaczyć dwojako. Po pierwsze - w kontekście polityki zagranicznej RFN początków XXI wieku i rozpowszechnionych w Niemczech nastrojów antyamerykańskich: Hans Mommsen twierdził, że Pożoga była przez czytelników rozumiana jako przestroga przed zaangażowaniem w amerykańsko-brytyjską inwazje na Irak („Głęboko zakorzeniona niechęć współczesnego niemieckiego społeczeństwa do użycia sił militarnych można wyjaśnić długofalowym oddziaływaniem wojny powietrznej" ${ }^{50}$ ), zaś Andreas Huyssen zauważył, że na początku XXI wieku niemiecka młodzież protestowała przeciw nalotom na Irak pod sloganem „Wiemy, co to znaczy być zbombardowanym" ${ }^{1}$. Po drugie - w perspektywie zjednoczenia RFN i NRD: naloty bombowe stanowiły bowiem ostatnie wspólne doświadczenie wschodniej i zachodniej części Niemiec $^{52}$. Ich ofiary opłakiwane były po obu stronach żelaznej kurtyny - choć, z przyczyn politycznych, w RFN eksponowane były w mniejszym stopniu niż w NRD, gdzie Drezno stało się symbolem „polityki imperializmu”53. Analogicznie, w RFN silniej dochodziła do głosu pamięć o wysiedlonych - z terytoriów włączonych do ZSRR lub państw pozostających w jego strefie wpływów; na „wyciszenie" pamięci o Dreźnie w RFN wpłynęła także książka Drezno. Apokalipsa (wyd. angielskie w 1963 roku; w RFN - rok później) - z uwagi na osobę jej autora, Davida Irvinga ${ }^{54}$ (później oskarżanego o „kłamstwo oświęcimskie”). W publikacji podawał on znacznie zawyżoną liczbę 130 tys. zabitych, skorygowaną do

${ }^{49}$ Aleida Assmann, On the (In)compatability of Guilt and Suffering, "German Life and Letters" 2006, Nr. 2, s. 195.

${ }^{50}$ Hans Mommsen, Moralisch, Strategisch, Zerstörerisch, [w:] Ein Volk von Opfern ..., s. 150. Sam Friedrich utrzymywał, że nie podziela antyamerykańskich nastrojów i nie przyłączy się do protestów przeciw wojnie w Iraku - z tego jednak tylko powodu, iż dzisiejsza technologia militarna jest precyzyjna i pozwala na unikanie ofiar cywilnych.

${ }^{51}$ Andreas Huyssen, Air War Legacies: From Dresden to Bagdad, [w:] Germans as Victims, s. 85 .

${ }^{52}$ Mary Nolan, Air Wars, Memory Wars, "Central European History” 2005, Vol. 38, No. 1, s. 22.

${ }^{53} \mathrm{~W}$ opublikowanej w NRD w 1955 roku pracy, autorstwa dyrektora Muzeum w Dreźnie, pojawiaja się sformułowania („masakra”, „anihiliacja”) podobne do użytych o kilka dekad później przez Friedricha (Max Saydewitz, Zerstörung und Wideraufbau von Dresden, Berlin 1955); zob. Bill Niven, GDR and the Memory of Bombing of Dresden, [w:] Germans as Victims, s. 128.

${ }^{54}$ David Irving, Drezno. Apokalipsa 1945, [brak tłumacza], Warszawa 2002. 
35 tys. w późniejszych publikacjach, których autorzy podkreślali, że naloty nie miały na celu pognębienia ludności cywilnej, lecz były skierowane na miejsca produkcji broni i ośrodki transportowe. Wiele prac historycznych poświęconych wojnie ukazało się w 2004 roku, na fali obchodów rocznicowych ${ }^{55}$; w prasowych recenzjach tych prac sugerowano, że można i należy je traktować jako „antidotum" na książkę Friedricha.

Nie można powiedzieć tego o filmie Drezno - najdroższej produkcji w historii niemieckiej telewizji (realizacja pochłonęła 10 milionów Euro). Za produkcję odpowiedzialna była wytwórnia TeamWorx należąca do Nico Hofmanna, który ma swym dorobku kilkanaście filmów i seriali historycznych. Paul Cooke zauważy ${ }^{56}$, iż podobnie jak w wypadku Gustloffa, również dla Drezna intertekstem jest Titanic Jamesa Camerona - z uwagi na użycie obrazów generowanych komputerowo, ale także ze względu na podobny motyw dramaturgiczny: bohaterki (w Dreźnie jest nią pielęgniarka Anna), która nie chce, zgodnie z wolą ojca (dyrektora szpitala), poślubić zamożnego oportunisty (chirurga Alexandra), lecz wikła się w romans z „wyklętym”.

W Dreźnie jest nim brytyjski lotnik, który musiał katapultować się z zestrzelonego samolotu i szuka schronienia w niemieckim szpitalu. Nazizm jest w tej przestrzeni „ciałem obcym” niemal na równi z Brytyjczykiem - z kręgu głównych bohaterów jedyną postacią o nazistowskim nastawieniu pozostaje siostra bohaterki, nawiązująca romans z działaczem NSDAP. Ojciec i narzeczony protagonistki przedstawieni zostaja jako zdrajcy - handluja wykradziona ze szpitalnej apteki morfina (pojawia się sugestia, że trafia ona do wysokich funkcjonariuszy NSDAP). Zbrodnie nazistowskie są wzmiankowane cokolwiek ogólnikowo (podczas spowiedzi, niemiecki żołnierz ranny na froncie wschodnim wyzna: "Robiłem różne rzeczy, straszne rzeczy"), odpowiedzialność za nie spada na „przeklętą wojnę" Te dwuznaczność w opowiadaniu o winie najlepiej unaocznia scena ukazująca infernalna pożoge po bombardowaniu - gdy Alexander oskarża Annę o niewierność (w podtekście: także zdradę narodu), wskazuje w niebo i wykrzykuje z wyrzutem: „To oni!”, na co kobieta odpowiada: „Nie, to my” (co można też rozumieć melodramatycznie - nie ma już „on i ja”, tylko „my” jako para zakochanych).

W wywiadach prezentujących intencje twórców oraz materiałach reklamowych podkreślano szczególna staranność w odtworzeniu realiów historycznych - akcentowano kwerendę archiwalną i zaangażowanie specjalistów akademickich do pracy nad filmem. Także w sposobie prowadzenia narracji zastosowano strategie uautentyczniające nakręcony materiał - najpierw w sekwencji, w której dokumentalny footage zostaje poprzedzony przez zrealizowane na potrzeby filmu ujęcia brytyjskiego lotnika rejestrujaccego kolegów wsiadających do samolotu, potem w sekwencji, gdy Anna i Robert ida przez spalone miasto; przez

${ }^{55}$ Friedrich Taylor, Dresden, February 13, 1945, New York 2004 (niemieckie wydanie w tym samym roku); Rolf-Dieter Müller, Der Bombenkrieg 1939-1945, Berlin 2004; Götz Bergander, Dresden in Luftkrieg: Vorgeschichte, Zerstörung, Folgen, Weimar 2004.

${ }^{56}$ Paul Cooke, "Dresden", Teamworx and "Titanic": German Wartime Suffering as Hollywood Disaster Movie, "German Life and Letters" 2008, No. 2. 
chwilę zreszta także oni sa zaprezentowani monochromatycznie (w ten sposób fikcjonalni bohaterowie zostają „wtłoczeni” w konwencję dokumentalna).

Na podstawie relacji naocznych świadków zbudowano najbardziej spektakularna sekwencję filmu, przedstawiajaca pożary wywołane przez bombardowanie. Zawiera ona wiele drastycznych ujeć (ludzie wyskakujacy przez okna, kobieta ciagnąca za sobą płonacy wózek), w tym takie, które moga budzić uzasadnione skojarzenia z narracją Friedricha: m.in. przedstawia podziemny schron wypełniony ciałami ludzi, którzy zatruli się tlenkiem węgla. Narracja filmu koncentruje się na ukazaniu niemieckiej perspektywy nalotów. Zamysłowi temu towarzysza chwyty montażowe - przykładowo, w scenach bombardowania, ścieżka dźwiękowa fokalizowana jest na Annie i Robercie (jeśli nagły wybuch bomby pozbawia ich na chwilę słuchu, ścieżka dźwiękowa odpowiednio cichnie); efekt ten jest dodatkowo wzmacniany przez ujęcia POV. Zarazem jednak kilka scen prezentuje motywacje brytyjskie (w filmie pokazane sa tylko naloty dokonywane przez RAF - choć na początku filmu Anna mówi: „Ci przeklęci Amerykanie, ta przeklęta wojna”). Sceny w sztabie RAF podkreślaja, że lotnicy musza „wykazać się" - choć maja świadomość, że wśród ofiar będą także cywile. Jeden z lotników mówi: „Moja siostra w Coventry poniosła śmierć w płomieniach. Nie uronię ani jednej łzy z powodu tych łajdaków tam na dole” - główna motywacja jest zatem zemsta ${ }^{57}$.

W dramaturgii podkreślony zostaje fakt, że ofiarami nalotów nie byli tylko Niemcy. Celowi temu służy przede wszystkim wątek Simona Goldberga i jego aryjskiej żony Anny - gdy Goldberg, jako Żyd (grającemu tę rolę gwiazdorowi, Kaiowi Wiesingerowi, doklejono „garbaty nos”, aby nadać mu bardziej semickie rysy), nie może wejść do schronu, Anna postanawia zostać z nim w mieszkaniu. Postać Goldberga wzorowana jest na Victorze Klempererze, którego Dzienniki, opisujace życie Żyda w nazistowskim Dreźnie, zostały wydane w 1995 roku i stały się w Niemczech bestsellerem ${ }^{58}$ (sfilmowano je także na potrzeby telewizji - Victor Klemperer - Mein Leben ist so sündhaft lang, reż. Ullrich Kasten, Wolfgang Kohlhaase, Niemcy 1999).

Drezno miało swa premiere na Berlinale w 2006 roku, kilka tygodni później - na poczatku marca - pokazane zostało w stacji ZDF. Oglądalność była imponujaca: pierwszego dnia film obejrzało 12,7 miliona widzów (33 procent widowni), część druga - 11,2 miliona ${ }^{59}$. Po premierze ukazało się kilka relacji z pokazów z udziałem osób, które przeżyły bombardowania - w ich wypowiedziach dominował ton, że w rzeczywistości wyglądały one jeszcze bardziej

${ }^{57}$ Aspekt ten podkreślają zwłaszcza autorzy opracowań anglojęzycznych: Stephan Jaeger, Visualisations of the Bombing of Dresden: The Efforts of German Television to Capture History, "Seminar" 2009, nr 45; David Crew, Sleeping with the Enemy? A Fiction Film for German Television about the Bombing of Dresden, "Central European History" 2007, No. 40; zob. także: Antonia Schmid, Der "Feuersturm" als Vollwaschprogramm: Zur Universalisierung des Opfers im Ferseh-Zweiteiler "Dresden", [w:] Deutschlandwunder. Wunsch und Wahn in der postfaschistischen Kultur, Bremen 2007.

${ }^{58}$ Victor Klemperer, Chce dawać świadectwo aż do końca: Dzienniki, przeł. A. i A. Klubowie, Kraków 2000.

${ }^{59}$ Dane za: Feuersturm mit Millionenpublikum, "Der Spiegel”, 7 marca 2006. 
przerażająco (zwracano uwagę, iż w filmie brak ujęć pokazujących nisko lecące samoloty, z których - ponoć - padały serie z karabinów maszynowych $)^{60}$.

Film zebrał dość dobre recenzje: często podkreślano spektakularność scen $\mathrm{z}$ użyciem obrazów generowanych komputerowo ${ }^{61}$, choć utyskiwano na wątek melodramatyczny. „Der Tagesspiegel” narzekał, że dramaturgia „wykazuje się inteligencją emocjonalną właściwa popołudniowym serialom szpitalnym”, a oglądając film ma się wrażenie „orgii magazynów o dekoracji wnętrz pod hasłem Piękne-Mieszkania-W-Trzeciej-Rzeszy”62. Recenzentka „Die Zeit” dostrzegła, że poczatek filmu jasno unaocznia przyczyny bombardowań (otwierające film słowa Hitlera "zmieciemy z powierzchni ziemi wasze miasta"), ale zarazem uznała, iż wraz z rozwojem akcji film nabiera "rewanżystowskiej dynamiki”: „Goebbels chciał, by wojna w ojczyźnie stała się żelazem, które hartuje się od uderzeń [...] W Dreźnie Niemcy jawia się niemal tak heroiczni, jak chciał tego Goebbels"63. Innego zdania była autorka wspomnianej recenzji z „Der Tagesspiegel”; w jej opinii nie można mówić o „rewanżyzmie”, gdyż jest to „przebrzmiały dyskurs, jak gdyby mówienie o cudzej winie było podejrzane i miało oznaczać relatywizowanie własnej winy [...] Samo mówienie o winie prowadzi na manowce. Nie chodzi już o przypisywanie winy, chodzi o przekazanie historycznego doświadczenia"64. Ten aspekt filmu podkreślał także - pracujący dla TeamWorx jako konsultant naukowy - znany historyk Hans Mommsen, który odcinając się od tez Friedricha, deklarował: „Drezno unika jakichkolwiek prób wyrównania rachunków, na pierwszy plan wysuwa odrzucenie wojny jako sposobu uprawiania polityki" ${ }^{65}$. Intencję tę odczytał recenzent ze „Stuttgarter Zeitung”: „Nie chodzi tu o pytanie o winowajców, ale o wojnę jako szaleństwo", dostrzegając zarazem, że polityczna wymowa filmu jest chwiejna: „Film chce zadośćuczynić wszystkim, chce byś w politycznym centrum. Ale nie zawsze się to udaje. Brytyjski oficer mówi o fali uciekinierów zmierzających na zachód - piloci wiedzieli więc, co bombarduja”ø6.

\section{Zatopienie Gustloffa - reprezentacje literackie i filmowe}

Drugim niemieckim „miejscem pamięci” skorelowanym z dyskursem cywilnych ofiar wojny jest statek Wilhelm Gustloff. Zwodowany w 1938 roku, przez jakiś czas służył jako prom turystyczny, podczas wojny zaś - jako okręt

${ }^{60}$ Christiane Kohl, Dresden - wie es wirklich war: Ein leiser Sirenenton, "Süddeutsche Zeitung", 7 marca 2006; Andreas Platthasu, Zeigt das Leben danach: Eine Trümmerfrau in der Film-Premiere von "Dresden", "Frankfurter Allgemeine Zeitung", 22 lutego 2006.

${ }^{61} \mathrm{~Np}$. Michael Hanfeld, „Dresden” in Fernsehen. In der Wut des Feuersturms, "Frankfurter Allgemeine Zeitung“, 20 lutego 2006.

${ }^{62}$ Kerstin Decker, Schuld und Schwester, "Der Tagesspiegel”, 4 marca 2006.

${ }^{63}$ Evelyn Finger, Der englische Pilot, "Die Zeit", 23 lutego 2006.

${ }^{64} \mathrm{~K}$. Decker, op. cit.

${ }^{65}$ Hans Mommsen, Eindrucksvolles Panorama der späten NS-Zeit, "Die Welt", 28 lutego 2006.

${ }^{66}$ Werner Birkenmaier, Die Frage der Plausibilität, "Stuttgarter Zeitung”, 8 marca 2006. 
treningowy dla marynarki wojennej. 30 stycznia 1945 roku wypłynął na pierwszy od lat rejs na morzu; na pokładzie znajdowało się około 8 tysięcy cywilów i 1000 żołnierzy marynarki wojennej oraz ranni żołnierze Wehrmachtu. W wyniku storpedowania statku przez sowiecki okręt podwodny, statek zatoną w okolicach Ustki; przeżyło około 1250 osób.

Temat Gustloffa został wprowadzony na forum niemieckiej debaty publicznej za sprawa noweli Günthera Grassa ${ }^{67}$, która odniosła niebagatelny sukces czytelniczy (zepchnęła Harry'ego Pottera na dwa tygodnie z czołówki bestsellerów) i uruchomiła dyskusję na temat generacyjnych hierarchii pamięci i sposobach opowiadania o niemieckich cierpieniach podczas wojny (problem tematyzowany przez sam sposób narracji - elipsy, omówienia i dygresje pokazuja, jak trudno narratorowi znaleźć właściwy język opisu wydarzeń i emocji). Dziennikarz Paul Pokriefke, główny bohater noweli, otrzymuje zlecenie napisania o tragedii Gustloffa; informacje na temat okoliczności zatonięcia statku są w narracji zapośredniczone przez relacje Tulli (postać o tym imieniu i nazwisku pojawiła się we wcześniejszych powieściach Grassa - Kot i mysz oraz Psie lata), matki Paula, która była obecna na pokładzie, oraz prowadzona przez jej wnuka Konrada stronę internetowa. Pierwsze rozdziały maja charakter sprawozdawczy przypominaja losy Wilhelma Gustloffa, nazistowskiego działacza zamordowanego w 1936 roku w Szwajcarii przez Davida Frankfurtera, chorwackiego Żyda. Imiona mężczyzn posłuża jako pseudonimy chłopców, którzy dyskutuja o historii na stronie internetowej; dochodzi do spotkania, podczas którego Konrad zabija „Davida” (a raczej Wolfganga). Gdy Konrad pokazuje ojcu model Gustloffa, który wykonał w poprawczaku, Paul zadaje w myślach pytanie: „Czy to się nigdy nie skończy?". A dowiedziawszy się, że dwójka neonazistów na nowo otworzyła stronę poświęconą Gustloffowi, odpowiada sobie - „To się nigdy nie skończy”...

Nowela sugeruje, że zaniechanie upamiętniania niemieckich ofiar w tekstach kultury będzie prowadzić do ekstremistycznych neonazistowskich zachowań, które moga być „rozbrojone” przez empatię z niemieckim cierpieniem. Ponieważ pokolenie 1968 roku (reprezentowane przez Paula) nie jest na to przygotowane, młodsza generacja (Konrad) wystawiona jest na ryzyko przejęcia punktu widzenia dziadków (Tulla). Czytana w tej optyce nowela Grassa ilustruje swoiste odwrócenie dyskursu polityki pamięci: jeszcze w latach osiemdziesiątych (choćby w „sporze historyków”) wydawało się, iż depozytariuszem pamięci jest lewica, która oponowała przeciwko nadaniu nazizmowi wymiaru historycznego; teraz to prawica „ożywia” przeszłość, a reprezentant lewicy skłania się ku temu, by o niej zapomnieć68.

Inaczej niż w Idac rakiem - i w odróżnieniu (toutes proportions gardées) od Drezna - współczesnej ramy narracyjnej nie zawiera film Gustloff w reżyserii głównego „wyrobnika” fabuł wojennych we współczesnej kinematografii

${ }^{67}$ Günter Grass, Idac rakiem, przeł. S. Błaut, Gdańsk 2002; zob. także: Hubert Orłowski: Przemoc - tabu - trauma ofiar. Wokót najnowszej powieści Güntera Grassa, [w:] idem: Zrozumieć świat. Szkice o literaturze i kulturze niemieckiej XX wieku, Poznań 2003.

${ }^{68}$ Maja Zehfuss, Wounds of Memory. The Politics of War in Germany, Cambridge 2007, s. 60-61. 
niemieckiej, Josepha Vilsmaiera. Podobnie jak inne jego realizacje, również Gustloff ma sznyt wysokobudżetowej produkcji (duża ilość statystów), gatunkowo oscylując między formuła filmu wojennego i melodramatu. W roli konsultanta historycznego zatrudniono zaś Heinza Schöna, autora najpoczytniejszej książki o zatonięciu Gustloffa, wydanej po raz pierwszy w 1952 roku $^{69}$; jego nazwisko gwarantować miało faktograficzną poprawność (swoją droga, filmowi Vilsmaiera nadano retrospektywnie walor inscenizowanego dokumentu - ujęcia z filmu zostały wykorzystane w dokumencie Upadek Gustloffa (Der Untergang der Gustloff) Guido Knoppa, który na płycie DVD z filmem Gustloff dołączono jako dodatek).

W swej wnikliwej analizie Gustloffa, Bill Niven nazywa go wprost „rewizjonistycznym", argumentując, że film w żadnej scenie nie sygnalizuje choćby śladu nazistowskich sympatii wśród cywilów, wojna jest zaś pokazana jako „konflikt między dobrymi Niemcami i złymi nazistami” ${ }^{70}$. Rzeczywiście, scenariusz (i sposób inscenizacji) ewidentnie podkreśla kontrast pomiędzy „cywilami” i „mundurowymi”. Niemieckim uchodźcom przypisano status podobny do więźniów obozu koncentracyjnego - sa stłoczeni za ogrodzeniem z drutu kolczastego (który próbuja sforsować, by dostać się na pokład ${ }^{71}$ ).

Fabuła nie pozostawia wątpliwości, kto jest winien katastrofie - wojskowe dowództwo okrętu, w szczególności arogancki posiadacz owczarka alzackiego, kapitan Wilhelm Petri (postać wzorowana na autentycznym dowódcy Gustloffa, kapitanie Wilhelmie Zahnie), który nalegał na wcześniejsze wypłynięcie, by jak najszybciej przetransportować swój oddział do portu w Kilonii. Druga negatywną postacia - przedstawiona w dość groteskowy sposób - jest oficer polityczny Escher (salę restauracyjna, która ma zostać przeznaczona na zakwaterowanie większej ilości uciekinierów, chce on wykorzystać na uroczystość ku czci Hitlera; miłość do wodza jest tak przeogromna, że w czasie ewakuacji mężczyzna wyskakuje za burtę z jego portretem pod pachą).

Zatapiając okręt, Rosjanie w zasadzie korzystaja z okazji - prawdziwym winowajca okazuje się sabotażysta na pokładzie Gustloffa - łącznościowiec Hagen Koch, sowiecki kolaborant, postać dość antypatyczna także z uwagi na swe cechy fizyczne. Ilekroć sowiecka łódź podwodna pojawia się na ekranie, jej obrazowi towarzyszy mroczna muzyka (która Nivenowi skojarzyła się ze Szczękami Spielberga ${ }^{72}$ ); wnętrze sowieckiej łodzi podwodnej ma charakter bez mała infernalny (ciemność rozpraszana jedynie przez czerwonawe światła),

${ }^{69}$ Heinz Schön, Tragedia Gustloffa, przeł. Jola Zepp, Zakrzewo 2006. Autor monografii oskarżany był o sympatyzowanie z kręgiem rewizjonistów - w 1998 roku opublikował artykuł w tomie dedykowanym Davidowi Irvingowi Odwaga prawdy. Historycy w kajdanach (Wagnis Wahrheit, Historiker in Handschellen? Festschrift für David Irving, red. Reinhard Uhle-Wettler, Kiel 1998), wydanym przez wydawnictwo Arndt-Verlag, kierowane przez członka NPD Dietmara Muniera (w okresie 1998-2007 Schön opublikował w tym wydawnictwie pięć książek). Zob. także: Sebastian Christ, Der ZDF-Fachberater und die Rechten, "Stern", 3 marca 2008.

${ }^{70}$ Bill Niven, The Good Captain and the Bad Captain: Joseph Vilsmeier's "Die Gustloff" and the Erosion of Complexity, "German Politics and Society" 2008, No. 4, s. 84-85.

${ }^{71}$ Ibidem, s. 91.

${ }^{72}$ Ibidem, s. 93. 
krążący po niej żołnierze nie sa zindywidualizowani, zaś ich wypowiedzi nie sa tłumaczone, co dodatkowo wzmaga efekt „dziwności”. Na początku filmu mamy zresztą sugestię, że kontaktujący się z Sowietami łącznościowiec Koch należał do komórki zorganizowanego ruchu oporu: dwójka młodych ludzi zostaje rozstrzelanych w porcie - kto wie zatem, czy gdyby Gestapo nie działało sprawniej i w porę odkryło zdradę Kocha, do tragedii by nie doszło?

„Dobrym Niemcem” jest Helmut Kehding - katalog jego „dobrych uczynków” (lub choćby intencji) jest długi: bohater ratuje nastolatka przed poborem, ostrzega przed wypłynięciem w rejs, chce uratować jak najwięcej cywilów, wskazuje na niedostatek kamizelek i łodzi ratunkowych, wykazuje troskę o ciężarna kobietę... Nieskazitelność protagonisty Bill Niven komentuje następująco: „Gdyby tylko Helmutowi pozwolono kierować okrętem, wszystko byłoby dobrze. Choć nosi mundur marynarki cywilnej, antycypuje ideał powojennej Bundeswehry - jest obywatelem w mundurze, powodowanym etycznymi pobudkami" ${ }^{\prime 3}$.

Oprócz tej trójki Niemców, na losy Gustloffa wpływ mają jeszcze dwaj kapitanowie: Johannsen (postać wzorowana na autentycznym kapitanie Petersenie), który nie jest w stanie przeciwstawić się Petriemu, oraz kapitan Leonberg, dowódca portu w Gdyni (nie odgrywa on żadnej roli podczas rejsu, ale najpierw próbuje powstrzymać Petriego przez podjęciem decyzji o wypłynięciu statku, a po jego zatonięciu pomaga Kehdingowi). W dyskursie filmu obaj pełnią funkcje Mitläuferów (wprawdzie noszą mundury, ale główne znaczenia, których są nośnikami, brzmią: „ci, którzy wykonywali rozkazy, nie musieli się z nimi zgadzać").

Helmut Kehding skontrastowany jest nie tylko z wojskowym dowództwem statku, ale także z bratem Haraldem, oficerem politycznym. To typowa postać „nawróconego” - gdy Helmut bezskutecznie próbuje uratować rannego brata, ten przed śmiercią zdąży jeszcze wyszeptać: „Znajdź Erikę, przytul ją do siebie, choć Ty nie bądź idiotą". Bohater postępuję zgodnie z tą rada - wraz $\mathrm{z}$ ukochana zdaży jeszcze adoptować urodzone na łodzi ratunkowej niemowlę, któremu nadadzą imię Harald. W ten sposób nazistowski opryszek otrzyma druga szansę - po „nawróceniu” został symbolicznie „reinkarnowany”, by współtworzyć przyszłość Niemiec.

Premierze filmu w styczniu 2008 roku nadano odświętny charakter - na pokaz, który odbył się w prestiżowym miejscu (kino Cinestar na Postdamer Platz, bankiet wydano w hotelu Ritz Carlton), przybyła Angela Merkel, wiceprzewodnicząca Bundestagu Susanne Kastner z SPD, szef klubu CDU/CSU Volker Kauder, a także Erika Steinbach i wielu innych parlamentarzystów ${ }^{74}$. Premiera na kanale telewizji publicznej ZDF odbyła się na początku marca 2008 roku; recenzje prasowe były przeważnie dość krytyczne. Wielu recenzentów pokusiło się o porównanie z Titanikiem Jamesa Camerona - dochodząc do wniosku, że

${ }^{73}$ Ibidem, s. 90.

${ }^{74}$ Parlaments-Kino. TV-Drama Die Gustloff feierte Premiere, "Der Tagesspiegel”, 23 stycznia 2008; Stille Koalition. 200 Parlamentarier sehen den TV-Untergang der "Gustloff", "Süddeutsche Zeitung", 24 stycznia 2008. 
wypada ono na niekorzyść niemieckiej produkcji (Andreas Kilb: „Oglądając film katastroficzny, chcemy zobaczyć, jak to się stało. W Gustloffie nie wiadomo, gdzie jest przód i tył, gdzie góra i dół”75). Kilku recenzentów zwróciło uwagę, iż wymowa filmu przypomina dyskursy dominujące w latach pięćdziesiątych Dietrich Kuhlbrodt naigrywał się $\mathrm{z}$ ujętej w filmie $\mathrm{w}$ bezosobową stronę bierną informacji „Padły strzały w Zatoce Gdańskiej” (bez dopowiedzenia, skąd się dobywały i czemu akurat właśnie tam), kwitujacc recenzje zgrabna frazą: „ZDF z czasów Adenauera żyje i ma się dobrze, niech żyje restauracja!"76; Stephan Maus w „Stern” pisał zaś: „Główną rolę w filmie odgrywa mgła nad Morzem Bałtyckim, za która znikaja wszystkie przyczyny katastrofy. Zbrodnie Wehrmachtu? Za mgła. Holocaust? Niewzmiankowany. Role ofiar obsadzili niemieccy cywile”, całość zaś wgląda tak, ,jakby Związek Wypędzonych trafił na bal kostiumowy"?7.

Niven wskazuje na różnice w wymowie Gustloffa i wcześniejszego filmu poruszającego wątek zatonięcia okrętu - Noc zapadta nad Gotenhafen (Nacht fiel über Gotenhafen, reż. Frank Wisbar, RFN 1959). W filmie Wisbara ważny jest wątek zdrady małżeńskiej popełnionej podczas nalotu przez Marię, żonę bohatera; mąż Kurt nie może jej tego wybaczyć, choć jest strofowany przez radiowca Becka, swojego przyjaciela „Nie możesz przykładać standardów z czasu pokoju do tej szalonej wojny" (wątek ten powróci w scenie frontowej - gdy bohatera o pomoc prosi Polka, której spalono dom, mężczyzna może jedynie westchnać: „Co ja mogę począć?”). Zdaniem Nivena, „O ile Wisbar poddaje krytyce pogląd, że kodeks moralny czasów pokoju mógł zostać utrzymany w czasie wojny, o tyle film Vilsmaiera jest tego poglądu potwierdzeniem"78.

$* * *$

Gustloffa i Drezno - jeśli analizować te filmy w perspektywie pamięci nazizmu - łączy kilka podobieństw. Po pierwsze, posługując się tymi filmami można zilustrować zmieniającą się ocenę działalności Wehrmachtu. Bill Niven czyta je wręcz przez pryzmat wystawy Reemtsy i Heera:

Filmy takie jak Dresden czy Gustloff dowodza, że niemiecka kultura popularna zaakceptowała oskarżenie kierowane przeciw Wehrmachtowi. A ponieważ Wehrmacht został zdyskredytowany, jest wykorzystywany jako wygodne miejsce składowania niemieckiej winy. Jednocześnie podejmowane są wysiłki, by oczyścić z winy tych, którzy nie byli częścią aparatu wojskowego, mianowicie niemieckich cywili ${ }^{79}$.

Rzeczywiście - w obu filmach wśród żołnierzy Wehrmachtu pojawiają się postaci znakowane aksjologicznie jako „źli”, zaś ofiary (nazistowskiej machiny wojennej, sowietów lub aliantów) to przede wszystkim ludność cywilna. 2008

${ }^{75}$ Andreas Kilb, Schmacht fiel über Gotenhafen, "Frankfurter Allgemeine Zeitung", 2 marca

${ }^{76}$ Dietrich Kuhlbrodt, Die Gustloff, "Konkret” 2008, Nr. 2.

${ }^{77}$ Stephan Maus, Hitlers Titanic, "Stern", 28 lutego 2008.

${ }^{78}$ Bill Niven, The Good Captain..., s. 96.

${ }^{79}$ Ibidem, s. 95. 
Po drugie, w obu filmach dochodzi do nawrócenia i symbolicznego włączenia do narodowej wspólnoty tych, którzy przyznali się do błędu (Harald w Gustloffie, ojciec Anny w Dreźnie). Co istotne, Niemcy „nawracaja się” bez zewnętrznej pomocy czy „reedukacji” - sami wytwarzaja warunki, w których odnowa moralna pojawia się samoczynnie, niejako „od środka”. Jak pisze Niven w odniesieniu do Gustloffa: „powojenny porządek moralny nie powstał w wyniku alianckiej reedukacji, ale z niemieckiej umiejętności zaleczenia ran wewnątrz własnego społeczeństwa" ${ }^{" 10}$. Uwagę tę z powodzeniem można też odnieść do Drezna.

Mamy jednak do czynienia z istotną różnica. W Dreźnie ma miejsce pojednanie Niemców i Brytyjczyków (romans pielęgniarki i lotnika) ${ }^{81}$. Z tej „paneuropejskiej wspólnoty” wykluczony zostaje jednak Związek Sowiecki w Gustloffie nie ma mowy o „sojuszu” sowiecko-niemieckim (łącznościowiec Koch popełnia samobójstwo). Ów pedagogiczny „kicz pojednania” jest najbardziej wyraźny w Dreźnie, zwieńczonym współczesną sekwencją dokumentalną (przemówienie prezydenta Horsta Köhlera podczas otwarcia Frauenkirche w październiku 2005 roku). Takie domknięcie narracji to ewidentny gest polityczny, eksponujący właściwy modus operandi mówienia o przeszłości (wyraźnie widoczne są flagi Unii Europejskiej). Zdaniem Cooke'a, widząc w zakończeniu staruszków przysłuchujących się mowie Koehlera, „nie można nie przypomnieć sobie zakończenia Listy Schindlera, w którym ocaleni składaja hołd bohaterom" ${ }^{82}$ - także sprawiedliwym Niemcom.

\section{Bibliografia}

Alliierter Bombenkrieg: Das Beispiel Dresden, red. L. Fritze, Th. Widera, Göttingen 2005.

Als Feuer vom Himmel fiel: Der Bombenkrieg in Deutschland, red. S. Burgdorff, Ch. Habbe, München 2003.

Assmann A., On the (In)compatability of Guilt and Suffering, "German Life and Letters" 2006, Nr. 2.

BeFreier und Befreite. Krieg, Vergewaltigungen, Kinder, red. H. Sander, B. Johr, München 1992.

Bergander G., Dresden in Luftkrieg: Vorgeschichte, Zerstörung, Folgen, Weimar 2004.

Birkenmaier W., Die Frage der Plausibilität, "Stuttgarter Zeitung", 8 marca 2006.

Boog H., Kolossalgemälde des Schreckens, [w:] Ein Volk von Opfern?, Die neue Debatte um den Bombenkrieg, 1940-1945, red. L. Kettenacker, Berlin 2005.

Boog H., Krebs G., Vogel D., Das deutsche Reich in der Defensive. Strategischer Luftkrieg in Europa, Stuttgart 2001.

Christ S., Der ZDF-Fachberater und die Rechten, "Stern", 3 marca 2008.

Cooke P., "Dresden", Teamworx and "Titanic": German wartime suffering as Hollywood Disaster Movie, "German Life and Letters" 2008, No. 2.

Crew D., Sleeping with the Enemy? A Fiction Film for German Television about the Bombing of Dresden, "Central European History" 2007, No. 40.

${ }^{80}$ Ibidem, s. 96.

${ }^{81}$ We wspomnianej Ucieczce - trzecim filmie telewizyjnym z okresu 2006-2008 dotyczacym cierpień niemieckich ofiar - mamy do czynienia z pojednaniem niemiecko-francuskim (niemiecka hrabina i francuski jeniec). Zob. Sonja M. Schultz, Der Nationalsozialismus im Film. Von "Triumph des Willens" bis "Inglorious Bastards", Berlin 2012, s. 436.

${ }^{82}$ P. Cooke, op. cit., s. 292. 
Darnstädt Th., Lauft, ihr Schweine!, "Spiegel” 2002, Nr. 14.

Decker K., Schuld und Schwester, "Der Tagesspiegel”, 4 marca 2006.

Deutsche Erinnerungorte, red. H. Schultze, Etienne François, München 2001.

Dückers T., Alles nur Opfer, "Zeit”, 5 marca 2008.

Ein Volk von Opfern? Die neue Debatte um den Bombenkrieg, 1940-1945, red. Lothar Kettenacker, Berlin 2005 .

Finger E., Der englische Pilot, "Die Zeit", 23 lutego 2006.

Fiuk E., Inicjacje, tożsamość, pamięć. Kino niemieckie na przełomie wieków, Wrocław 2012.

Frei N., 1945 und wir. Das Dritte Reich im Bewusstsein der Deutschen, München 2005.

Friedrich J., Die Brandstätten. Der Anblick des Bombenkriegs, München 2003.

Friedrich J., Pożoga: bombardowania Niemiec w latach 1940-1945, przeł. P. Dziel, D. Kocur, J. Liniwiecki, Warszawa 2011.

Grass G., Idac rakiem, przeł. S. Błaut, Gdańsk 2002.

Groehler O., Bombenkrieg gegen Deutschland, Berlin 1990.

Grossmann A., A Question of Silence: The Rape of German Women by Soviet Occupation Soldiers, [w:] Women and War in the Twentieth Century: Enlisted with or without Consent, ed. N. A. Dombrowski, New York-London 1999.

Hage V., Hamburg 1943: Literarische Zeugnisse zum Feuersturm, Frankfurt am Main 2003.

Hage V., Zeugen der Zerstörung: Die Literaten und der Luftkrieg, Frankfurt am Main 2003.

Hahn H. H., Jak w Niemczech pamięta się o wypędzeniu, "Borussia" 2007, nr 4.

Hanfeld M., "Dresden" in Fernsehen. In der Wut des Feuersturms, "Frankfurter Allgemeine Zeitung", 20 lutego 2006.

Hauptmann G., Dresden, [w:] idem, Sämtliche Werke, red. Hans-Egon Hass, tom XI, Frankfurt am Main 1974.

Helbig L. F., Der ungeheure Verlust. Flucht und Vertreibung in der deutschsprachigen Belletristik, Wiesbaden 1996.

Hillers M., Anonyma, Kobieta w Berlinie: zapiski z 1945 roku, przeł. B. Tarnas, Warszawa 2004.

Huyssen A., Air War Legacies: From Dresden to Bagdad, [w:] Germans as Victims, op. cit.;

Huyssen A., Present Pasts: Urban Palimsests and the Politics of Memory, Stanford 2003.

Irving D., Drezno. Apokalipsa 1945, [brak tłumacza], Warszawa 2002.

Jaeger S., Visualisations of the Bombing of Dresden: The Efforts of German Television to Capture History, "Seminar" 2009, No. 45.

Jirgl R., Niedopetnieni, przeł. R. Wojnakowski, Olsztyn 2009.

Kempowski W., Das Echolot. Fuga furiosa. Ein kollektives Tagebuch. Winter 1945, München 1999-2005.

Kempowski W., Der rote Hahn. Dresden in Februar 1945, München 2001.

Kilb A., Schmacht fiel über Gotenhafen, "Frankfurter Allgemeine Zeitung", 2 marca 2008.

Klemperer V., Chce dawać świadectwo aż do końca: Dzienniki, przeł. A. i A. Klubowie, Kraków 2000.

Kohl Ch., Dresden - wie es wirklich war: Ein leiser Sirenenton, "Süddeutsche Zeitung", 7 marca 2006.

Lemberg H., Frenzen E., Die Vertriebene, Hitlers letzte Opfern, Berlin 2002.

Margalit G., Der Luftkrieg auf Dresden. Seine Bedeutung für die Erinnerungspolitik der DDR, [w:] Narrative der Shoah. Repräsentationen der Vergangenheit in Historiographie, Kunst und Politik, red. S. Düwell, M. Schmidt, Paderborn 2002.

Margalit G., Dresden and Hamburg - Official Memory and Commemoration of the Victims of Allied Air Raids in the two Germanies, [w:] A Nation of Victims?, Representations of German Wartime Suffering from 1945 to the Present, red. H. Schmitz, Amsterdam 2007.

Maus S., Hitlers Titanic, "Stern", 28 lutego 2008.

Mommsen H., Eindrucksvolles Panorama der späten NS-Zeit, "Die Welt", 28 lutego 2006.

Mommsen H., Moralisch, Strategisch, Zerstörerisch, [w:] Ein Volk von Opfern?, Die neue Debatte um den Bombenkrieg, 1940-1945, red. L. Kettenacker, Berlin 2005.

Müller O., Schlesisches Wetter, Berlin 2003.

Müller R.-D., Der Bombenkrieg 1939-1945, Berlin 2004. 
Narrative der Shoah. Repräsentationen der Vergangenheit in Historiographie, Kunst und Politik, red. Susanne Düwell, Matthias Schmidt, Paderborn 2002.

Neumann Thomas W., Der Bombenkrieg: Zur ungeschriebenen Geschichte einer kollektiven Verletzung, [w:] Nachkrieg in Deutschland, red. Klaus Naumann, Hamburg 2001.

Neutzner Matthias, Vom Alltäglichen zum Exemplarischen. Dresden als Chiffre für Luftkrieg der Allierten [w:] Das Rote Leuchten: Dresden und der Bombenkrieg, red. Oliver Reinhard, Matthias Neutzner, Dresden 2005.

Niven B., GDR and the Memory of Bombing of Dresden, [w:] Germans as Victims, red. B. Niven, Basingstoke 2006.

Niven B., The Good Captain and the Bad Captain: Joseph Vilsmeier's "Die Gustloff" and the Erosion of Complexity, "German Politics and Society" 2008, No. 4.

Noack H.-J., Die Deutsche als Opfer, "Der Spiegel” 2002, Nr. 13.

Nolan M., Air Wars, Memory Wars, "Central European History" 2005, Vol. 38, No. 1.

Orepuk M., Skażona pamięć o bombardowaniach Drezna, „Kultura Współczesna” 2008, nr 4.

Orłowski H., Zrozumieć świat. Szkice o literaturze i kulturze niemieckiej XX wieku, Poznań 2003.

Platthasu A., Zeigt das Leben danach: Eine Trümmerfrau in der Film-Premiere von "Dresden", "Frankfurter Allgemeine Zeitung", 22 lutego 2006.

Saydewitz M., Zerstörung und Wideraufbau von Dresden, Berlin 1955.

Schmid A., Der „Feuersturm” als Vollwaschprogramm: Zur Universalisierung des Opfers im Ferseh-Zweiteiler „Dresden”, [w:] Deutschlandwunder. Wunsch und Wahn in der postfaschistischen Kultur, Kittkritik Verlag, Bremen 2007.

Schmitz H., The Birth of the Collective from the Spirit of Empathy: From the 'Historians' Dispute' to German Suffering, [w:] Germans as Victims, ed. B. Niven, Basingstoke 2006.

Schmitz H., The Return of Wartime Suffering in Contemporary German Memory Culture, Literature and Film, [w:] A Nation of Victims? Representations of German Wartime Suffering from 1945 to the Present, ed. H. Schmitz, Amsterdam 2007.

Schön H., Tragedia Gustloffa, przeł. J. Zepp, Zakrzewo 2006.

Sebald W. G., Wojna powietrzna i literatura, przeł. M. Łukasiewicz, Warszawa 2012.

Taberner S., "Normalisation", the New Consensus on the Nazi Past and the Problem of German Wartime Suffering, "Oxford German Studies" 2002, No. 31.

Taylor F., Dresden, February 13, 1945, New York 2004.

Trajman J., Narodowy socjalizm w kinie zjednoczonych Niemiec, Wrocław 2014.

Trenkner J., Wieluń 1. September 1939: Keine besondere Feindbeobachtung, [w:] Ein Volk von Opfern?, Die neue Debatte um den Bombenkrieg, 1940-1945, red. L. Kettenacker, Berlin 2005.

Wahrheit W., Historiker in Handschellen? Festschrift für David Irving, red. R. Uhle-Wettler, Kiel 1998.

Walser M., Bombenkrieg als Epos, [w:] Ein Volk von Opfern?, Die neue Debatte um den Bombenkrieg, 1940-1945, red. L. Kettenacker, Berlin 2005.

Welzer H. et al., „Dziadek nie byt nazista”. Narodowy socjalizm i Holocaust w pamięci rodzinnej, [w:] Pamięć zbiorowa i kulturowa. Wspótczesna perspektywa niemiecka, red. M. Saryusz-Wolska, Kraków 2009.

Widera Th., Gefangene Erinnerung: Die politische Instrumentalisierung der Bombardierung Dresdens, [w:] Alliierter Bombenkrieg: Das Beispiel Dresden, red. L. Fritze, Th. Widera, Göttingen 2005.

Wiegrefy K., Eine teuflische Lösung, "Spiegel” 2002, Nr. 15.

Zehfuss M., Wounds of Memory. The Politics of War in Germany, Cambridge 2007. 